Article

\title{
Synthesis and Comparative Evaluation of Novel Cationic Amphiphile C12-Man-Q as an Efficient DNA Delivery Agent In Vitro
}

\author{
Gunita Apsite ${ }^{1}$, Irena Timofejeva ${ }^{1}$, Aleksandra Vezane ${ }^{1}$, Brigita Vigante ${ }^{2}$, Martins Rucins ${ }^{2}$, \\ Arkadij Sobolev ${ }^{2}$, Mara Plotniece ${ }^{2,3}$, Karlis Pajuste ${ }^{2}$, Tatjana Kozlovska ${ }^{1}$ and Aiva Plotniece ${ }^{2, *}$ \\ 1 Latvian Biomedical Research and Study Centre, Ratsupites iela 1, LV-1067 Riga, Latvia; \\ gunita.apsite@gmail.com (G.A.); irena@biomed.lu.lv (I.T.); \\ Aleksandra.Vezane@biomed.lu.lv (A.V.); tatyana@biomed.lu.lv (T.K.) \\ 2 Latvian Institute of Organic Synthesis, Aizkraukles iela 21, LV-1006 Riga, Latvia; vigante@osi.lv (B.V.); \\ rucins@osi.lv (M.R.); arkady@osi.lv (A.S.); marap167@hotmail.com (M.P.); kpajuste@osi.lv (K.P.) \\ 3 Rīga Stradinš University, Dzirciema iela 16, LV-1007 Riga, Latvia \\ * Correspondence: aiva@osi.lv; Tel.: +371-6701-4852
}

Received: 28 May 2018; Accepted: 21 June 2018; Published: 26 June 2018

\begin{abstract}
New amphiphilic 1,4-DHP derivative C12-Man-Q with remoted cationic moieties at positions 2 and 6 was synthesised to study DNA delivery activity. The results were compared with data obtained for cationic 1,4-DHP derivative D19, which is known to be the most efficient one among the previously tested 1,4-DHP amphiphiles. We analysed the effects of C12-Man-Q concentration, complexation media, and complex/cell contact time on the gene delivery effectiveness and cell viability. Transmission electron microscopy data confirms that lipoplexes formed by the compound C12-Man-Q were quite uniform, vesicular-like structures with sizes of about $50 \mathrm{~nm}$, and lipoplexes produced by compound D19 were of irregular shapes, varied in size in the range of 25-80 nm. Additionally, confocal microscopy results revealed that both amphiphiles effectively delivered green fluorescent protein expression plasmid into BHK-21 cells and produced a fluorescent signal with satisfactory efficiency, although compound C12-Man-Q was more cytotoxic to the BHK-21 cells with an increase of concentration. It can be concluded that optimal conditions for C12-Man-Q lipoplexes delivery in BHK-21 cells were the serum free media without $0.15 \mathrm{M} \mathrm{NaCl}$, at an N/P ratio of 0.9. Compound D19 showed higher transfection efficiency to transfect BHK-21 and Cos-7 cell lines, when transfecting active proliferating cells. Although D19 was not able to transfect all studied cell lines we propose that it could be cell type specific. The compound C12-Man-Q showed modest delivery activity in all used cell lines, and higher activity was obtained in the case of H2-35 and B16 cells. The transfection efficiency in cell lines MCF-7, HeLa, and Huh-7 appears to be comparable to the reference compound D19 and minimal in the HepG2 cell line.
\end{abstract}

Keywords: cationic amphiphiles; 1,4-dihydropyridines; lipoplexes; DNA transfection; gene delivery; cytotoxicity

\section{Introduction}

Gene therapy has become the research focus for many laboratories in pharmacy, medicine, biochemistry, and chemical engineering worldwide [1,2]. In gene therapy DNA, RNA, or gene activity controlling elements are used as pharmacological agents to cure diseases by replacing damaged genes with a proper one [3-6]. Initially, gene therapy was viewed as an approach for treating hereditary diseases, but its potential role in the treatment of acquired diseases, such as cancer, is now widely recognised [7-9]. 
The success of gene therapy is largely dependent on the development of a vector or vehicle that can selectively and efficiently deliver a gene to target cells with minimal toxicity [10-12]. The two main types of vectors that are used in gene therapy are based on viral and nonviral gene delivery systems. Though viral systems usually give high transfection efficiency, safety concerns from potential mutation, recombination, oncogenic effect, and high cost, however, greatly limit their therapeutic applications $[13,14]$. Compared to viral vectors, nonviral gene delivery systems are known to possess a low preexisting immunogenicity. Additional advantages of nonviral vectors are their higher loading capacity and facile preparation methods [15]. Consequently, the development of novel nontoxic cationic structures with high gene transfection efficiencies is of great importance [16].

Synthetic cationic lipids are widely used components of nonviral gene carriers and the factors regulating their transfection efficiency are subject of considerable interest [17]. Synthetic cationic lipids are currently the most extensively used nonviral carriers due to their ability to form complexes with the nucleic acids [18]. The structure of the lipid molecule, for example, the functional nature hydrophobic domain and the charged headgroup, has a significant impact on the particle integrity and morphology and, hence, on transgene efficiency and cytotoxicity [19]. Each lipid has different structural aspects, such as headgroup size and hydrocarbon tail length. These aspects confer distinct characteristics to the lipid/DNA complex, which, in turn, affect association with, and uptake into, the cell [20]. The molecular architecture of the cationic lipid determines its transfection efficiency [21].

Positively-charged amphiphilic 1,4-dihydropyridine (1,4-DHP) derivatives were studied earlier as membranotropic compounds [22] and proposed as a promising tool for DNA delivery [23,24]. Previously, multiple cationic 1,4-dihydropyridine amphiphiles capable of transfecting plasmid DNA (pDNA) into different cell lines in vitro were developed. After these studies we have concluded that two cationic moieties at positions 2 and 6, together with dodecyloxycarbonyl substituents at positions 3 and 5 of the 1,4-DHP molecule, were optimal for these kinds of synthetic lipid-like compounds [23,24]. The obtained data confirmed that, at charge ratio 2, the transfection efficiency of 1,4-DHP amphiphile D19 was about five times better than that reported for the commercially available cationic lipid of DOTAP ( $N$-(1-(2,3-dioleoyloxy)propyl)- $N, N, N$-trimethyl ammonium methylsulfate). The compound was also 45 times more effective than PEI 25 (polyethyleneimine of $25 \mathrm{kDa}$ ) [24]. Recently, the influence of the amphiphile core on the efficacy of pDNA delivery has been revealed within studies of structure-activity relationships performed by our research group. During these studies the activity of the corresponding cationic pyridines as close structural analogues, and possible metabolites of promising 1,4-DHP delivery systems, were examined. The obtained data showed that pyridine derivatives having dodecyloxycarbonyl substituents at positions 3 and 5 , and cationic moieties at positions 2 and 6, possessed lower pDNA transfection activity than the corresponding 1,4-DHP amphiphiles [25].

In this study two promising cationic compounds on 1,4-DHP core were studied. Compound C12-Man-Q was synthesised for testing of the influence of remoted cationic moieties at positions 2 and 6 of the 1,4-DHP molecule on DNA delivery activity. The design of compound C12-Man-Q was based on the exchange of aromatic pyridinium moieties of derivative D19 to aliphatic ammonium moieties. The results were compared with data obtained for cationic 1,4-DHP derivative D19, which is known to be the most efficient one among the 1,4-DHP derivatives tested previously [23-25]. In this work we analysed the effects of C12-Man-Q concentration, complexation media, and complex/cell contact time on the gene delivery effectiveness and cell viability on various cell lines.

\section{Result and Discussion}

\subsection{Synthesis of Cationic 1,4-Dihydropyridine Derivatives D19 and C12-Man-Q}

The reference compound 1,1'-[(3,5-didodecyloxycarbonyl-4-phenyl-1,4-dihydropyridine-2,6-diyl)d imethylen]-bispyridinium dibromide (D19) was synthesised according to the already-reported method [23], path A (Scheme 1). The target 1,4-DHP derivative $N, N^{\prime}-\{[3,5$-bis(dodecyloxycarbonyl)-4-p 
henyl-1,4-dihydropyridine-2,6-diyl]diethylene\}bis $N, N$-dimethyloctyl ammonium dibromide (C12-Man-Q) was designed to remain in two cationic moieties at positions 2 and 6 and dodecyloxycarbonyl substituents at positions 3 and 5 of the 1,4-DHP molecule which were defined as optimal for these kinds of synthetic lipid-like compounds as delivery systems according to our previous studies [23,24]. In this case, remoted 1,4-DHP cycle cationic aromatic headgroups were exchanged with aliphatic headgroups at positions 2 and 6 providing compound C12-Man-Q. Studies of the differences in activities of D-19 and C12-Man-Q are important steps in establishing the structure-activity relationships and elaboration of more active and selective cationic 1,4-DHP derivatives in the future. The desired cationic 1,4-DHP derivative C12-Man-Q was synthesised in the two-stage procedure according to path B (Scheme 1).

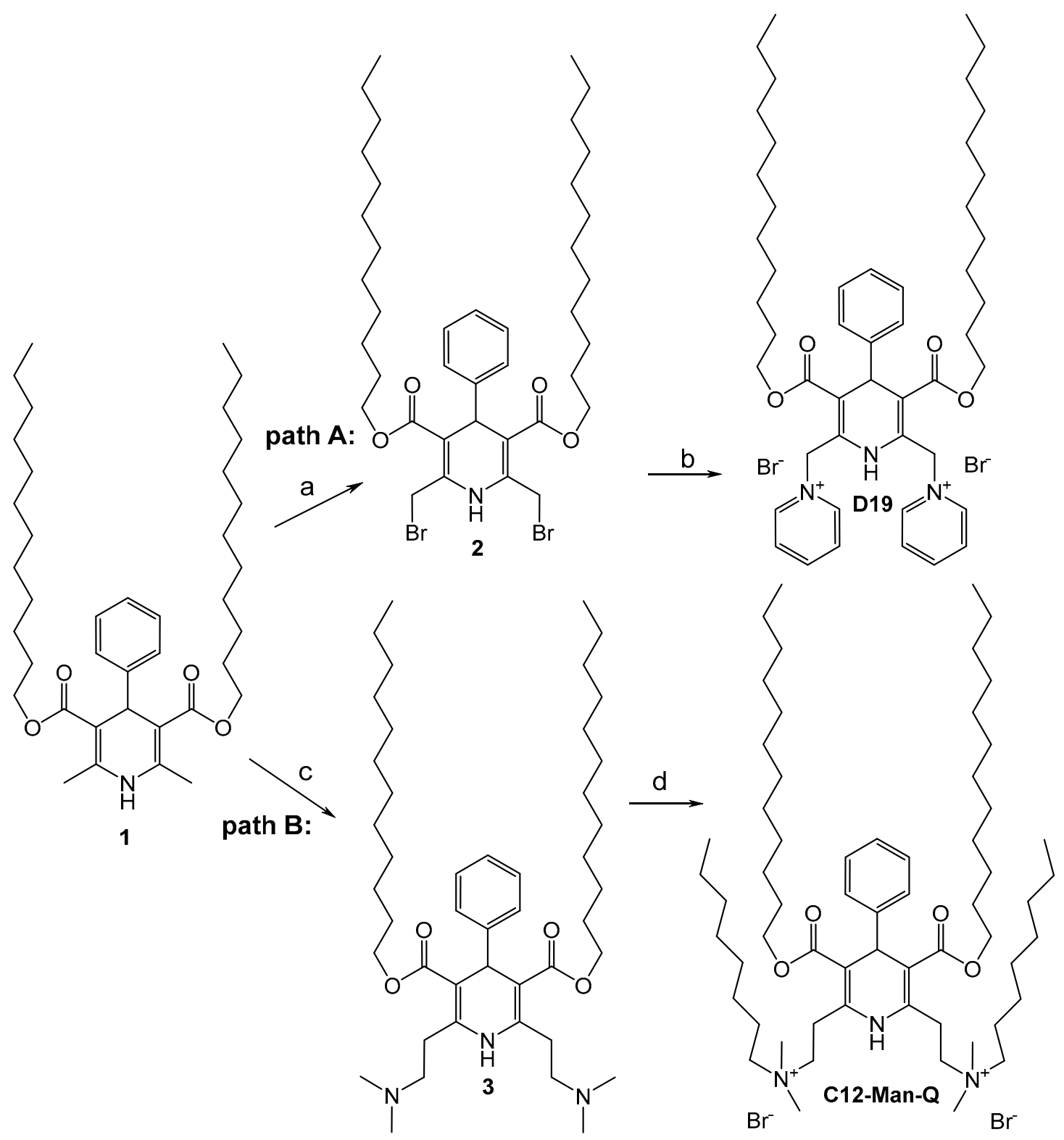

Scheme 1. Strategies for the synthesis of cationic 1,4-DHP derivatives D19 and C12-Man-Q. Reaction conditions: (a) NBS, MeOH, r.t., 20 h; (b) pyridine, dry acetone, r.t. 48 h [26]; (c) paraformaldehyde, dimethylamine hydrochloride, EtOH, conc.HCl, reflux, 24 h; and (d) 1-bromooctane, nitromethane, DMF, reflux, $48 \mathrm{~h}$. 
2,6-Bis(2-(N,N-dimethylamino)ethyl) 1,4-dihydropyridine derivative 3 was obtained in $68 \%$ yield in the Mannich reaction, analogous with the method reported in the literature [27]. In our case product purification was performed by flash chromatography. It can be assumed that the Mannich reaction occurred with a lower yield due to the presence of didodecyloxycarbonyl substituents at the positions 3 and 5 of 1,4-DHP cycle, compared to the previously-described methoxycarbonyl moieties [27], which were less sterically hindered. Further quaternisation of 1,4-DHP 3 with 1-bromooctane with continuous refluxing in a mixture of nitromethane and DMF led to the target aliphatic moieties containing dicationic 1,4-DHP derivative C12-Man-Q in 50\% yield.

The structures of the newly-synthesised compounds 3 and C12-Man-Q were established and confirmed by ${ }^{1} \mathrm{H}-\mathrm{NMR},{ }^{13} \mathrm{C}-\mathrm{NMR}$, MS, and elemental analysis data. Details of the syntheses and full physico-chemical characterisation for the newly-synthesised compounds are given in the Experimental section. The purities of the studied compounds were at least $95 \%$ according to high-performance liquid chromatography (HPLC) data [28].

\subsection{Choice of Plasmid DNA}

Plasmid DNA (pDNA), as a DNA vector for transferring different genes of interest, has been widely used as gene delivery systems in vitro [29]. Plasmid vectors were classified into different classes in accordance to specificity of existing replication origin, selection markers and promoter sequences [30]. In this study, two plasmid vectors with relatively similar sizes (4079 bp and $4731 \mathrm{bp}$ ) and the same, strong constitutive cytomegalovirus (CMV) promoter [31] for transcriptional control of two different reporter genes' expression were used. Plasmid pRL-CMV (Promega, Madison, WI, USA) was used for delivery of the wild-type Renilla luciferase gene, thus allowing the evaluation of the transfection efficiency quantitatively. Plasmid pEGFP-C1 (Clontech) encoded for a red-shifted variant of wild-type GFP [32-34], which has been optimised for brighter fluorescence and higher expression in mammalian cells, was used to assess transfection efficiency visually with fluorescent microscopy. Interpretation of the results is based on the assumption, that although absolute gene expression values vary with the plasmid construct, the relative expression levels for various transfection reagents are related directly to the reagent and not to the plasmid $[35,36]$.

\subsection{Evaluation of Complexation Ability}

Formation of complexes (lipoplexes) between lipids and DNA is defined as the electrostatic interaction between anionic-charged DNA and the cationic-charged gene delivery vehicle. The first step in the gene delivery process is evaluation of the complexation ability of the carrier molecule with the pDNA, followed by pDNA condensation and formation of the carrier/pDNA complex. The N/P ratio refers to ionic balance in cationic amphiphiles/DNA transfection lipoplexes and indicates the ratio between nitrogen $(\mathrm{N})$ from the synthetic lipid and phosphate $(\mathrm{P})$ residues from the DNA. In most cases, in order to achieve higher transfection efficiency, it is crucial for the transfection complex to stay positively charged so that it could interact with cell plasmatic membrane on the same electrostatic forces basis [37-39]. Therefore, the relative pDNA binding affinities of the synthesised 1,4-DHP amphiphiles D19 and C12-Man-Q were evaluated using a standard electrophoresis gel shift assay for the assessment of pDNA (pEGFP-C1) complexation at various N/P ratios. Increasing the amounts of the compounds C12-Man-Q or D19 were mixed with a constant amount $(1 \mu \mathrm{g})$ of plasmid DNA (pEGFP-C1) and analysed by agarose $(0.9 \%, w / v)$ gel electrophoresis. The assay is based on the ability of free negatively-charged pDNA to migrate into the gel upon application of an electrical field, whereas complexed pDNA lacks this property. The formation of the D19/DNA complexes as evaluated in serum-free cell growth medium while C12-Man-Q/DNA complexes were evaluated both in serum free cell growth medium and in the same medium supplemented with $\mathrm{NaCl}(0.15 \mathrm{M})$ at various amphiphile/DNA (N/P) ratios. $\mathrm{NaCl}$ is an important component of most biological fluids, including serum. Even-Chen et al. demonstrated that for cationic lipid compositions, the addition of $\mathrm{NaCl}$ prevented lipoplex formation and induced partial dissociation between lipids and DNA of 
the preformed lipoplexes [40]. $\mathrm{NaCl}$ additive in transfection media was also used in our previous studies for development of 1,4-DHP amphiphiles as pDNA delivery agents and evaluated 1,4-DHP amphiphile D19 as a perspective delivery system [23,24].

The binding affinities of the studied 1,4-DHP amphiphiles D19 and C12-Man-Q are represented in Figure 1. The efficiency of pDNA complexation increased, along with growing the amphiphile/DNA complexes' $\mathrm{N} / \mathrm{P}$ ratio. The ability to complex the pDNA was approved by evident disappearance of supercoiled and linear forms of the pDNA for both compounds. For compound D19 almost all pDNA has been bound at $\mathrm{N} / \mathrm{P}$ ratio of 2 , which is in a good agreement with our previous data $[23,24]$. The effectiveness of 1,4-DHP derivative C12-Man-Q in lipoplex formation was influenced by complexation media and decreased up to $20 \%$ in the presence of $0.15 \mathrm{M} \mathrm{NaCl}$ (Figure $1 \mathrm{~B}$ ). It was confirmed that media significantly affected the complexation ability of compound C12-Man-Q, which was in agreement with other group conclusions, that transfection medium properties (ionic strength, counterion species, and $\mathrm{pH}$ ) were very important and affected cell surface and lipoplex electrostatics [40].

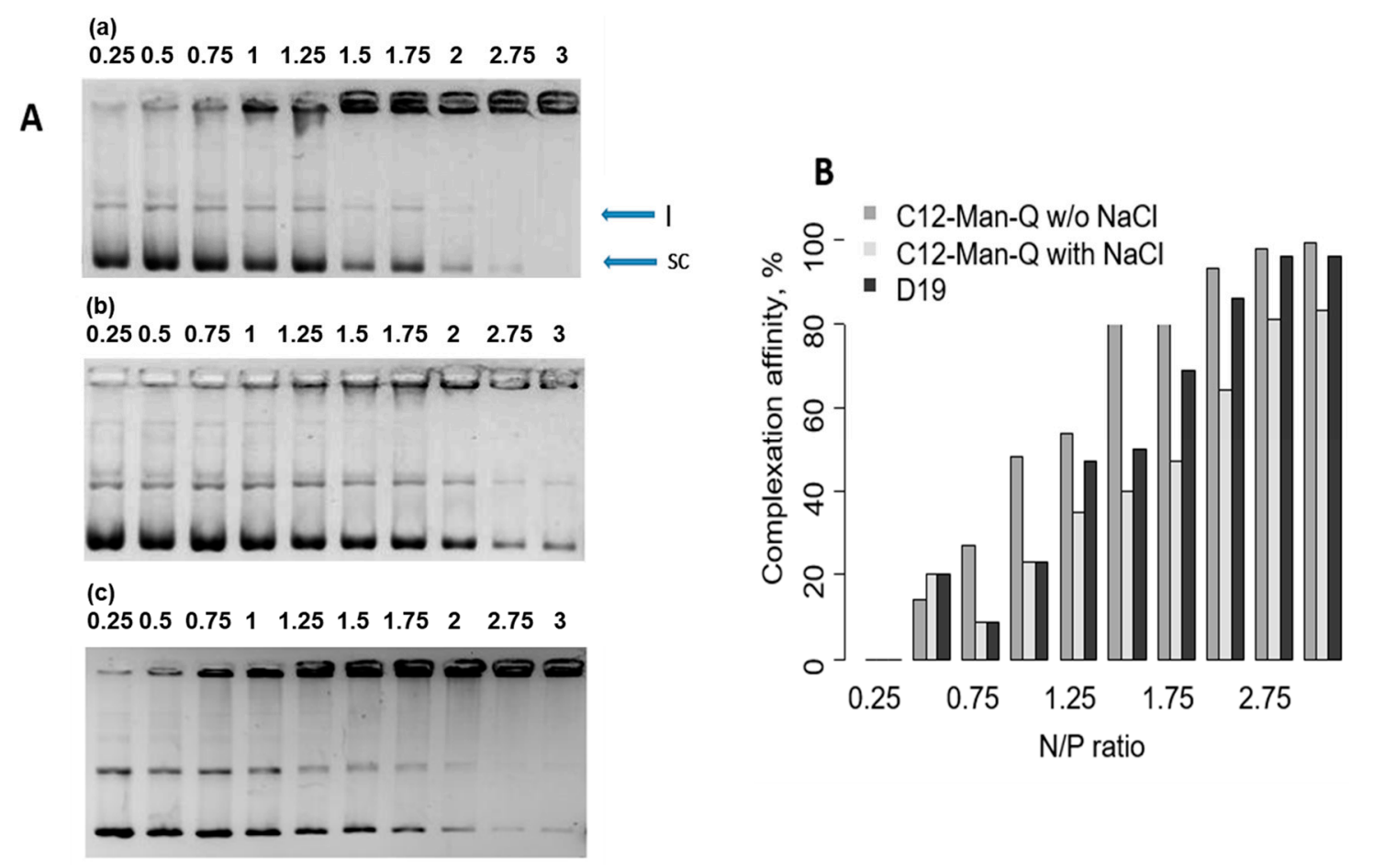

Figure 1. pDNA (pEGFP-C1) and cationic amphiphiles affinity test obtained by gel electrophoresis assay at various N/P (0.25-3) ratios. Supercoiled (sc) and linear (1) forms of plasmid DNA indicated by arrows. (A) pDNA retardation assay: (a) for C12-Man-Q/pDNA complexes without $\mathrm{NaCl}$; (b) for C12-Man-Q/pDNA complexes with $0.15 \mathrm{M} \mathrm{NaCl}$; (c) for D19/pDNA complexes with NaCl; and (B) quantification of the pDNA binding shift by densitometry (the percentage of the bonded supercoiled DNA was assessed by the density of bands on agarose gel using the open-access image processing program ImageJ) [41].

Among factors regulating the activity of transfection complexes, the size of the lipoplexes has been reported to be a major determinant of transfection efficiency [42-44]. The morphology and size of the lipoplexes formed by 1,4-DHP amphiphiles C12-Man-Q and D19 were analysed by the transmission electron microscopy (TEM) technique. As seen in TEM images (Figure 2), lipoplexes formed by the compound C12-Man-Q (Figure 2A) were quite uniform, about $50 \mathrm{~nm}$ in size and resembled vesicular-like structures. In turn, lipoplexes produced by compound D19 (Figure 2B) were of irregular shapes and these complexes varied in their size in the range 25-80 nm. 

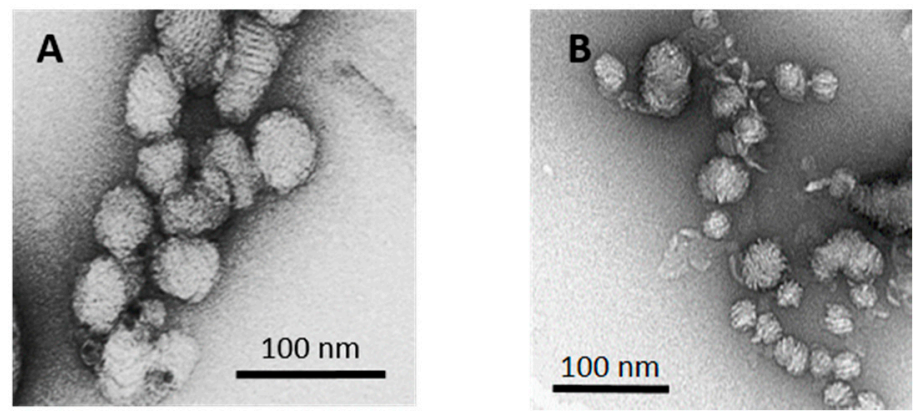

Figure 2. Transmission electron microscopy (TEM) images of lipoplexes formed by cationic lipid and pDNA (pEGFP-C1) at optimised N/P ratio. (A) lipoplexes formed by amphiphile C12-Man-Q (N/P ratio of 0.9); and (B) lipoplexes formed by amphiphile D19 (N/P ratio of 2). Scale bars represent $100 \mathrm{~nm}$.

Obtained data about lipoplex sizes for compound D19 coincide well with previous results, confirming that compound D19 and its structural analogues having different alkyl chains at 3,5-positions of 1,4-DHP and pCMV- $\beta$ Gal plasmid containing the $\beta$-galactosidase cDNA driven by the CMV promoter formed lipoplexes with diameters in the range below $150 \mathrm{~nm}$ [23].

\subsection{Cytotoxicoty Evaluation of 1,4-DHP/DNA Complexes}

The cytotoxic effect of the lipoplexes formed by 1,4-DHP amphiphiles/DNA towards mammalian cells was evaluated using colorimetric 3-(4,5-dimethylthiazol-2-yl)-2,5-diphenyltetrazolium bromide (MTT) assay [45]. The cells were treated with 1,4-DHP amphiphile/DNA complexes at various N/P ratios. Obtained data for the viability of BHK-21 cells are presented in Figure 3.
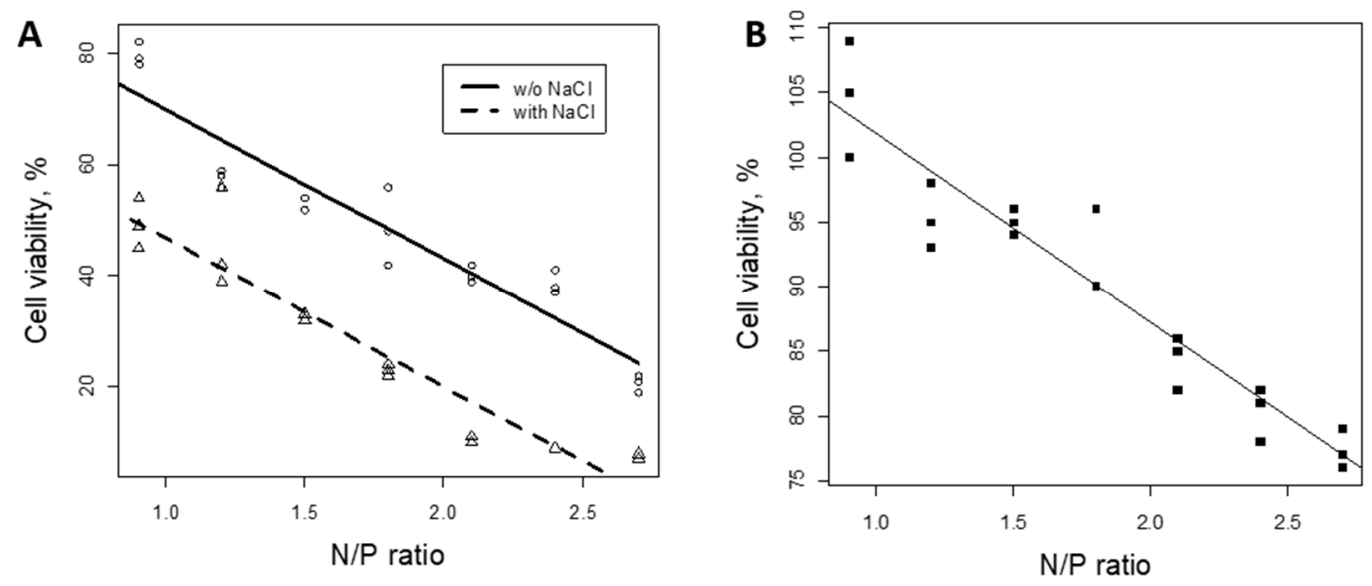

Figure 3. Viability of BHK-21 cells (\%) $24 \mathrm{~h}$ post transfection determined by MTT assay. (A) C12-Man-Q/DNA complexes; (B) D19/DNA complexes. DNA-pEGFP-C1. For each value of the N/P ratio three independent repeats were performed.

As shown in Figure 3, linear coherence between the used amount of 1,4-DHP amphiphiles and the viability of BHK-21 cells is evident for both compounds. An increase of the N/P ratio means decreasing cell viability. In general, lipoplexes formed by compound C12-Man-Q are more toxic to cells, and the toxicity is increased when $\mathrm{NaCl}(0.15 \mathrm{M})$ is used as an additive of lipoplex formation medium (Figure 3A). Thus, lipoplexes of compound C12-Man-Q showed only 50\% cell viability, when the lowest N/P ratio of 1 was used. Cell viability results were improved when the transfection complexes were prepared in medium without the addition of $\mathrm{NaCl}$, giving $50 \%$ cell viability at an $\mathrm{N} / \mathrm{P}$ ratio of 2. In turn, lipoplexes formed by compound D19 (Figure 3B) showed minimal toxic 
effect on BHK-21 cells. Moreover, compound D19, evidently, does not affect cell division and, as a result, cell viability values $24 \mathrm{~h}$ post transfection are even higher (above 100\%) than that of control, non-transfected cells.

It should be noted that evaluation of Cos-7 cell morphology after treatment with C12-Man-Q/DNA (pEGFP-C1) lipoplexes (Figure 4A) does not reveal any signs of toxicity caused by the used transfection reagent. Therefore, we could assume that different cell types might have different responses to treatment by C12-Man-Q/DNA lipoplexes, thus proving that the optimal transfection reagent for each cell line needs to be determined empirically. Synthesis of new series of cationic amphiphiles differing in cationic substituents may lead to the development of new prospective transfection reagents in the future.
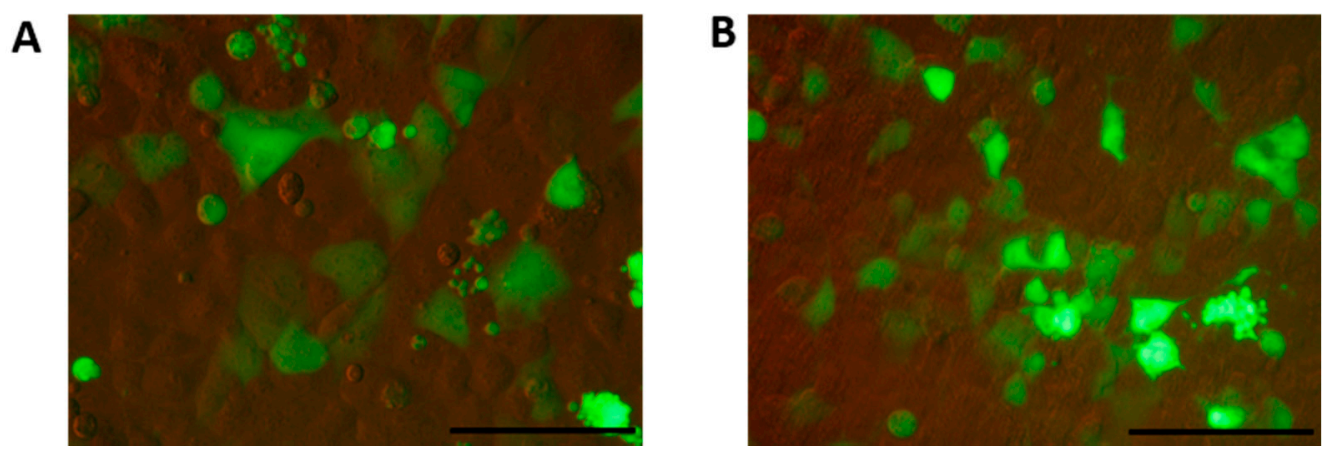

Figure 4. Cos-7 cell morphology evaluated by fluorescent microscopy $24 \mathrm{~h}$ post transfection with 1,4-DHP/DNA (pEGFP-C1) lipoplexes. (A) C12-Man-Q/DNA lipoplexes; and (B) D19/DNA lipoplexes. Scale bars represent $100 \mu \mathrm{m}$.

\subsection{Evaluation of Transfection Activity}

To evaluate the efficiency of the compounds C12-Man-Q and D19 to deliver plasmid DNA into mammalian cells, first, we performed a transient transfection of BHK-21 cell line. The expression vector pRL-CMV was used to evaluate the transfection efficiency of the new transfection agent C12-Man-Q at various $\mathrm{N} / \mathrm{P}$ ratios. Increasing amounts of C12-Man-Q were mixed with $1 \mu \mathrm{g}$ of $\mathrm{pDNA}$ to achieve $\mathrm{N} / \mathrm{P}$ ratios varying from 0.25 to 3.0 , and transfection activity of the lipoplexes was assessed by the luciferin-luciferase reaction test (Renilla luciferase assay system) [46]. Obtained data for transfection activity of 1,4-DHP amphiphiles in BHK-21 cells are presented in Figure 5. According to the obtained data lipoplexes formed by C12-Man-Q/DNA in media with $\mathrm{NaCl}$ additive demonstrated moderate, yet steady, transfection efficiency beginning from an $\mathrm{N} / \mathrm{P}$ ratio of 0.5 with no significant drop of the activity along with the increase of $\mathrm{N} / \mathrm{P}$ ratios up to 3.0 (Figure $5 \mathrm{~A}$, curve 2), and in media without $\mathrm{NaCl}$ additive, maximal transfection efficiency at an $\mathrm{N} / \mathrm{P}$ ratio of 0.9 , gradually decreasing to an $\mathrm{N} / \mathrm{P}$ ratio of 3 (Figure 5A, curve 1). By the obtained data C12-Man-Q can be characterised as rather inefficient in transfection of BHK-21 cells and, in this case, with completely different action compared with the reference compound D19. Obtained data confirmed that the compound D19 showed dose-dependent incensement of transfection activity at an N/P ratio of 2.4; after that, the activity slowly decreased (Figure 5B). The maximum delivery activity of compound D19 exceeded the transfection activity of C12-Man-Q by almost eight times in BHK-21 cells.

It was also noted earlier that the properties of the transfection medium (ionic strength, counter ion species, and $\mathrm{pH}$ ) are very important, because of the effect on cell surfaces and lipoplex electrostatics [40,47], which confirms the $\mathrm{NaCl}$ additive's influence on C12-Man-Q delivery efficiency.

A promising nonviral transfection gene delivery vehicle should have high transfection activity, but also low cytotoxicity, as cellular damage is an important event accompanying transfection [48,49]. Furthermore, it has long been recognised that different transfection reagents cause different levels of cytotoxicity in different cell lines [50]. 

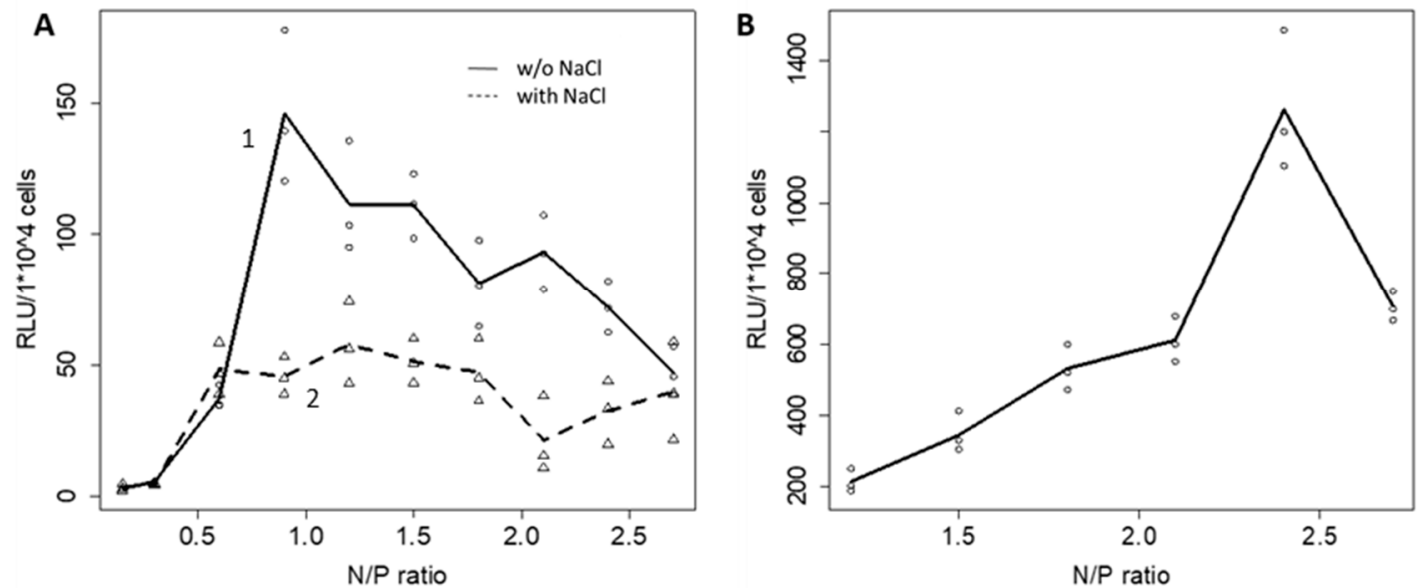

Figure 5. Transfection efficiency achieved using 1,4-DHP amphiphiles determined by luciferase enzyme activity $24 \mathrm{~h}$ post transfection. (A) Compound C12-Man-Q (1-without $\mathrm{NaCl}$; 2-with $\mathrm{NaCl}$ additive); and $(B)$ compound D19. For each value of the N/P ratio three independent repeats were performed.

The influence of 1,4-DHP/DNA lipoplexes on BHK-21 cell morphology changes ( $24 \mathrm{~h}$ after transfection) were evaluated by confocal fluorescent microscopy. The obtained data are presented at Figure 6.
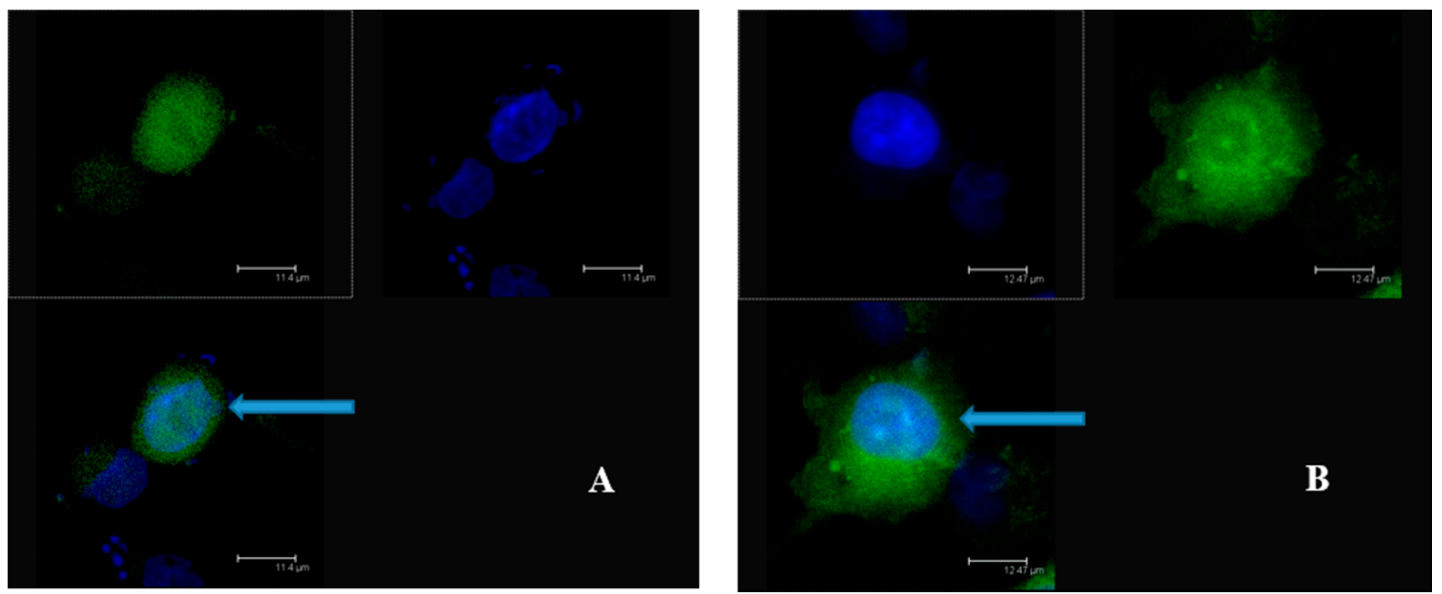

Figure 6. BHK-21 morphology changes (24 h after transfection) under the influence of lipoplexes of C12-Man-Q (A) and D19 (B) analysed by confocal fluorescent microscopy. Blue (DAPI)—nucleus of the cell, green EGFP expression in transfected cells transfection complex. Scale bars represent $100 \mu \mathrm{m}$.

Confocal microscopy results revealed that both amphiphiles C12-Man-Q and D19 delivered a green fluorescent protein expression plasmid into BHK-21 cells and produced a fluorescent EGFP signal with satisfactory efficiency. However, for the new compound C12-Man-Q cytotoxicity of the preformed transfection complexes (Figure 6A), revealed as distinct morphological changes (cell shrinkage) in transfected BHK-21 cells, was one of the most important factors that negatively influenced 1,4-DHP derivative C12-Man-Q transfection potential. Oppositely, the reference compound D19, as a part of the transfection complex, did not affect the transfected cell morphology, as evidenced by the predominantly uniform cytoplasmic distribution of EGFP fluorescence in cells (Figure 6B).

Simultaneously, we evaluated the influence of ionic strength of the complexation medium and optimised the contact time between the lipoplex and the cell surface on cytotoxicity and transfection efficiency of C12-Man-Q lipoplexes. Initially, the influence of ionic strength on BHK-21 cell morphology 
after transfection by C12-Man-Q/pEGFP-C1 lipoplexes were evaluated in the serum free media with and without $0.15 \mathrm{NaCl}$ additive [23]. The obtained data are presented in Figure 7.
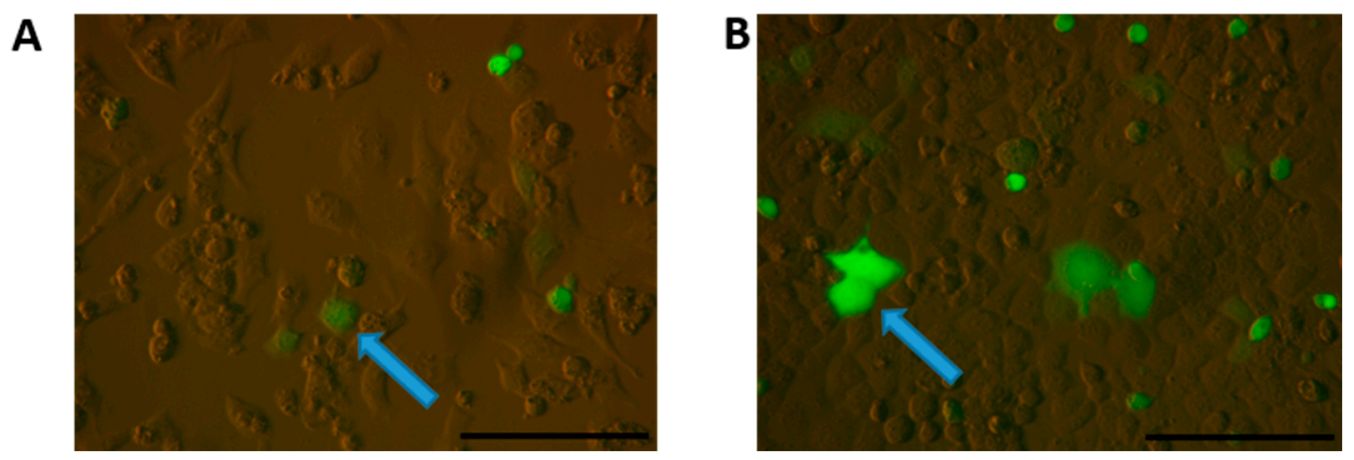

Figure 7. Influence of the ionic strength of the lipoplex formation medium on BHK-21 cell morphology changes $24 \mathrm{~h}$ after transfection by C12-Man-Q/pEGFP-C1 lipoplexes. (A) lipoplexes prepared in medium containing $0.15 \mathrm{M} \mathrm{NaCl}$; and (B) lipoplexes prepared in medium without the addition of $\mathrm{NaCl}$. Green cells represent transfected cells, which express pEGFP. Scale bars represent $100 \mu \mathrm{m}$.

Comparison of the morphology of BHK-21 cells (Figure 7) transfected by C12-Man-Q/pEGFP-C1 lipoplexes showed the effect of $\mathrm{NaCl}$ on cell proliferation. The density of cells in the Figure 7A is about $50 \%$ compared to Figure 7B, where the cell density is almost $100 \%$. The $\mathrm{NaCl}$ effects on the cells are seen at Figure 7 . This effect has resulted in reduced cell viability and also led to the conclusion that increments of ionic strength of complexation medium are the reason for the enhanced toxicity of C12-Man-Q for BHK-21 cell (Figures 5 and 6).

The results revealed that C12-Man-Q lipoplexes transfection efficiency on BHK-21 cells could be improved by decreasing the ionic strength of the lipoplex formation medium. As a result transfection efficiency was increased up to three times, when $\mathrm{NaCl}$ was removed from the C12-Man-Q/DNA complex formation medium (Figure 5A, curve 1). Thus, for an efficient BHK-21 cell transfection the optimal complexation medium for compound C12-Man-Q was a serum-free medium without $\mathrm{NaCl}$ and the highest transfection activity was achieved when the N/P ratio was 0.9 ; afterwards, the transfection activity slowly decreased. These conditions were used for the following evaluation of transfection efficiency for compound C12-Man-Q.

The optimal contact time between lipoplexes and transfecting cells is a rather complex parameter and depends on several factors that influence lipoplex size and stability [51]. Contact time of transfection complexes with cells ranges from $1 \mathrm{~h}$ to continuous exposure until the time of analysis [35]. In order to decrease the toxic impact of C12-Man-Q-formed lipoplexes on BHK-21 cells, the optimal contact time of lipoplexes and cells was established. We performed correlation analysis to determine whether the reduction of the contact time in half would cause a significant effect on transfection efficiency. The obtained results are presented in Figure 8.

After analysis of the obtained data, it was concluded that there was no significant impact of reducing the incubation time on transfection efficiency (Figure 8B). At the same time the significant improvement of cell viability was observed (Figure 7). Thus, it could be concluded that complexation time for lipoplexes prepared with compound C12-Man-Q can be reduced twice without any loss in transfection efficiency, but with a minimisation to lipoplex cytotoxicity.

Optimisation of the key parameters of the transfection protocol allows us to maximize transfection efficiency of the BHK-21 cells by C12-Man-Q-formed lipoplexes up to three times (Figure 9). 

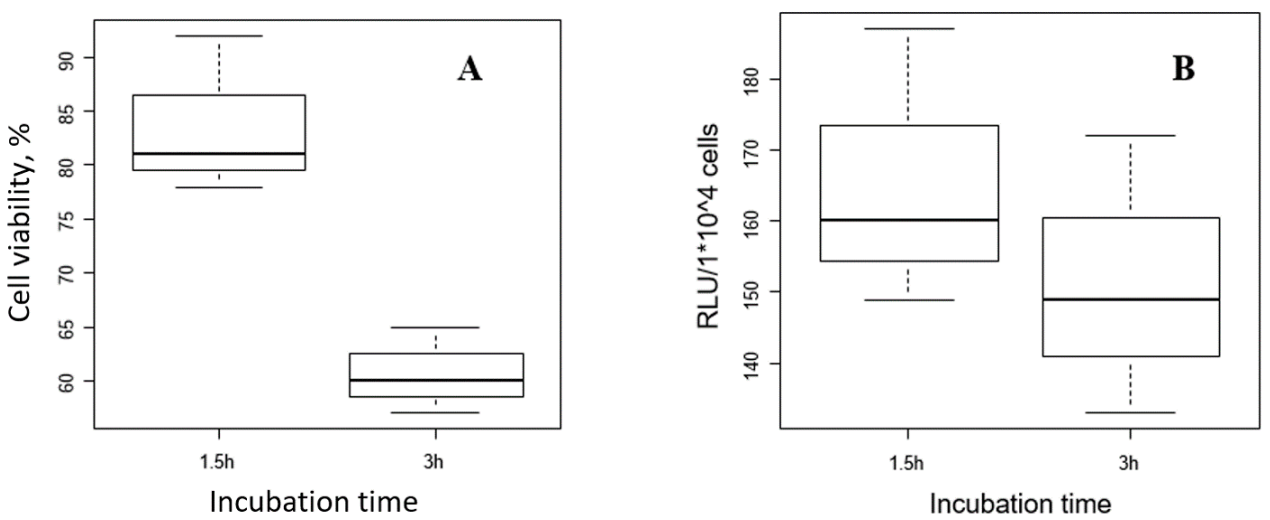

Figure 8. Optimisation of the C12-Man-Q/pDNA (pRL-CMV) lipoplexes/cell contact time on BHK-21 cells; N/P ratio of 0.9; sample prepared without additional NaCl. (A) The impact of the lipoplexes/cell contact time on the cell viability, determined $24 \mathrm{~h}$ post transfection by MTT test; and (B) the impact of lipoplexes/cell contact time on transfection efficiency determined by luciferase enzyme activity.
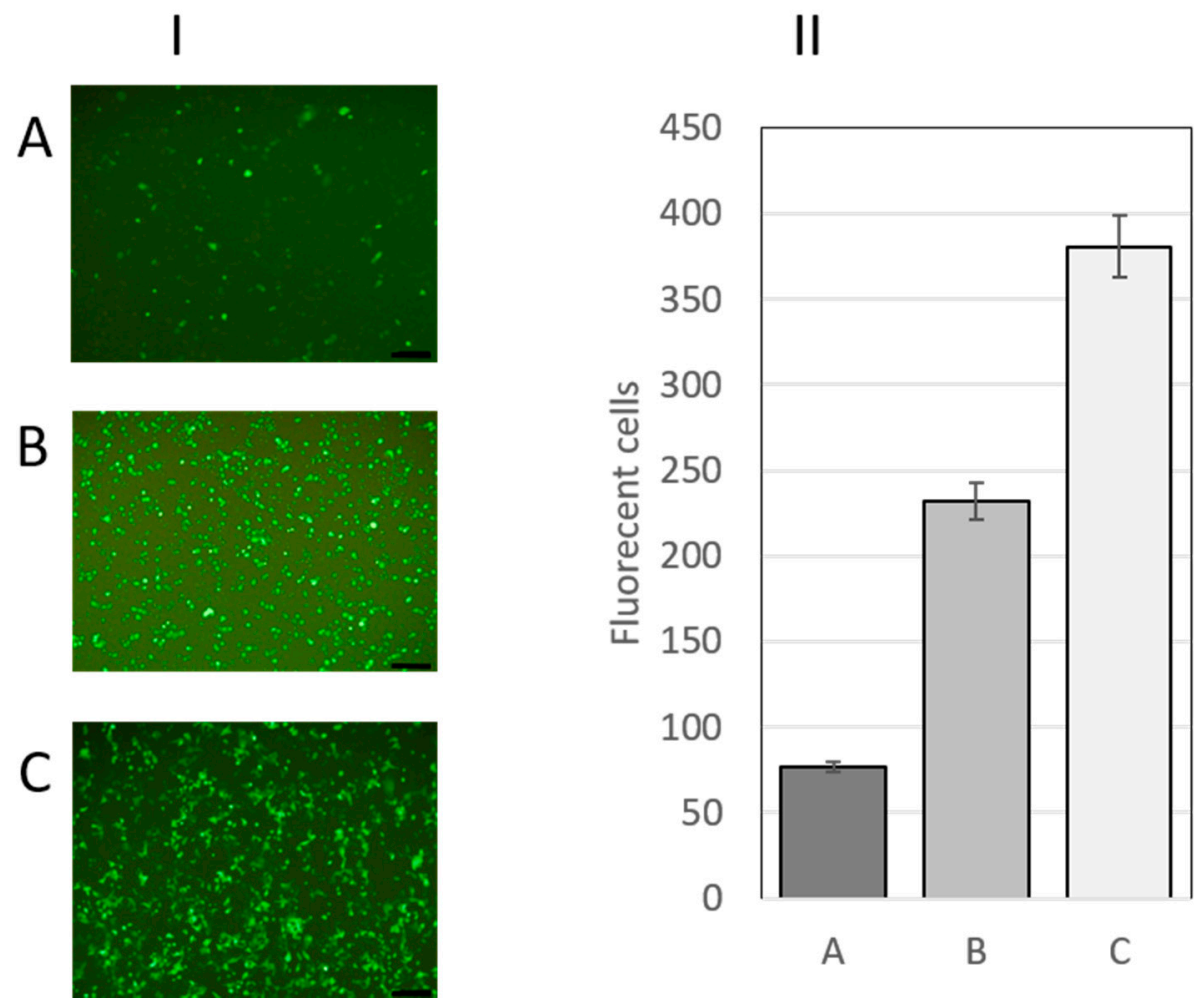

Figure 9. Influence of transfection parameters (lipoplex formation medium and lipoplex/cell contact time) on transfection efficiency of C12-Man-Q in BHK-21 cells in comparison to the reference compound D19. (I): evaluation of EGFP production in cells by fluorescent microscopy (scale bars represent $100 \mu \mathrm{m}$ ): (A) transfection by C12-Man-Q lipoplexes performed under standard conditions; (B) transfection by C12-Man-Q after optimisation of the key parameters of the transfection protocol; (C) transfection by the reference compound D19; (II): quantification of the influence of transfection parameters was assessed by amount of fluorescent cells using the open-access image processing program ImageJ.

Optimisation of the key parameters of the transfection protocol demonstrate that the 1,4-DHP derivative C12-Man-Q also works as gene delivery agent though still inferior to the reference 
compound D19. Obtained information regarding structure-activity relationships will be helpful for future design of DNA delivery agents on the base 1,4-DHP amphiphiles.

\subsection{Cell Line-Dependent Differences in Transfection Efficiency of the New Amphiphilic 1,4-DHP Derivative C12-Man-Q}

Since transfection efficiency can significantly contrast among different cell lines, it is an absolute perquisite to evaluate new nonviral gene delivery vehicle transfection efficiency in various cell lines. In general, it was underlined that, in many cases, transfection efficiency mediated by nonviral vectors is affected strongly by the cell type [52].

Thus, in addition to previously analysed BHK-21 and Cos7 cell lines, for evaluation of transfection ability of the new potential gene delivery agent C12-Man-Q, cancer cell lines H2-35, B16 (both of mouse origin), and MCF-7, HeLa, Huh-7, and HepG2 (of human origin) were chosen (Figures 10 and 11). The compound possessed moderate transfection efficiency, but was active in all cell lines used, showing promising potential for in vivo applications. Results were compared with data obtained for derivative D19 which is the most efficient among the previously studied 1,4-DHP derivatives [23-25].
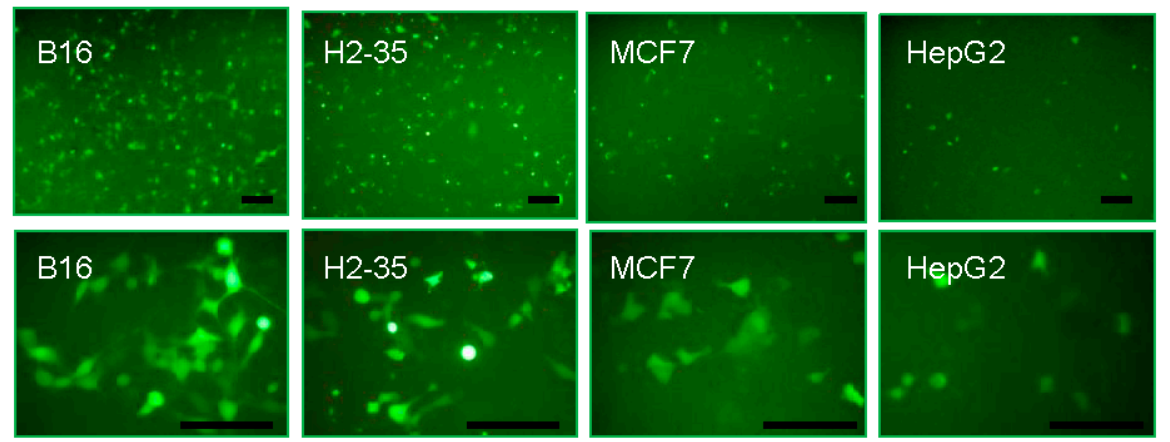

Figure 10. Assessment of transfection efficiency of the C12-Man-Q lipoplexes in cancer cell lines by fluorescent microscopy: B16 and H2-35 (both of mouse origin), and MCF-7 and HepG2 (human origin). Scale bars reflect $100 \mu \mathrm{m}$.

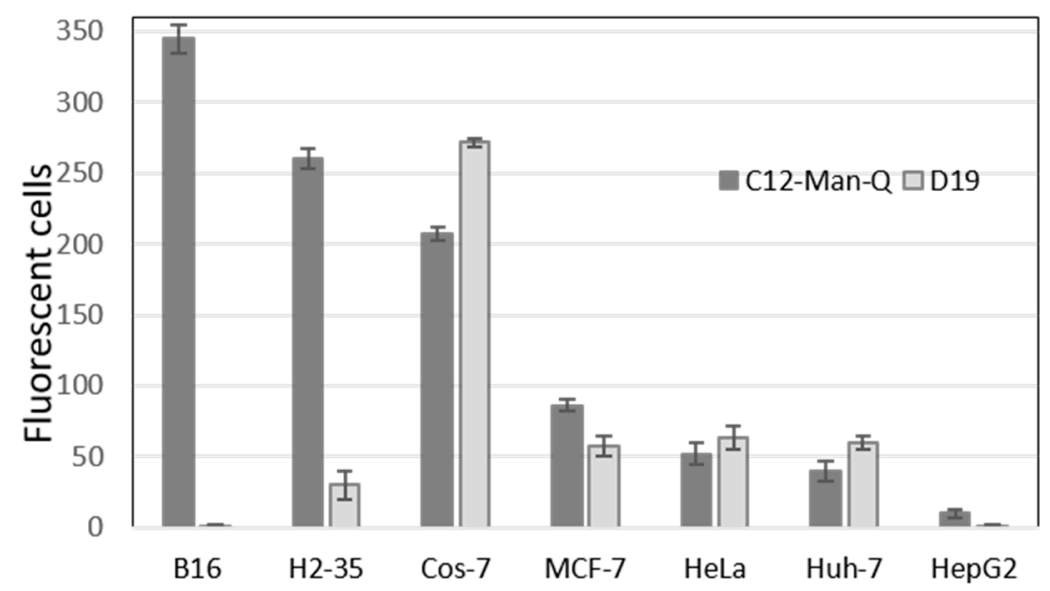

Figure 11. The comparison of the transfection efficiency of the studied amphiphilic 1,4-DHP derivatives C12-Man-Q and D19 in B16, H2-35, Cos-7, MCF-7, HeLa, Huh-7, and HepG2 cell lines. Image analysing program ImageJ was used to count fluorescent cells in the field of view.

We used the open-access image analysing program Image to count fluorescent cells in the field of view (Figure 11). Compound D19 showed greater transfection efficiency to transfect cell lines BHK-21 (Figure 9); Cos-7 (Figure 11), but did not succeed in transfecting HepG2 and B16 cell lines. 
The compound C12-Man-Q showed rather high delivery activity in the case of H2-35 and B16 cells, while towards other cell lines this compound displayed only modest activity (Figure 11). The transfection efficiency in cell lines MCF-7, HeLa, and Huh-7 was found to be comparable to the reference compound D19, while for the HepG2 cell line almost no activity was observed. In general, there should be careful optimisation for every type of cell line because of differences in their metabolic states, lipoplex uptake, and cell trafficking machineries.

\section{Materials and Methods}

\subsection{General}

All reagents were purchased from Acros Organics (Geel, Belgium) or Alfa Aesar (Lancashire, UK) and used without purification. TLC was performed on Silica gel 60 F254 aluminium sheets $20 \times 20 \mathrm{~cm}$ (Merck KGaA, Darmstadt, Germany). ${ }^{1} \mathrm{H}-\mathrm{NMR}$ spectra were recorded with a Varian Mercury BB (400 MHz) spectrometer and ${ }^{13} \mathrm{C}-\mathrm{NMR}$ spectra were recorded with a Varian Mercury BB $(100.56 \mathrm{MHz})$ spectrometer (Agilent, Santa Clara, CA, USA). The coupling constants are expressed in Hertz (Hz). The chemical shifts of the hydrogen and carbon atoms are presented in parts per million (ppm) and referred to the residual signals of the non-deuterated $\mathrm{CDCl}_{3}(\mathrm{~d}: 7.25)$ or partially-deuterated DMSO- $d_{6}$ (d: 2.50) solvent for ${ }^{1} \mathrm{H}-\mathrm{NMR}$ spectra and $\mathrm{CDCl}_{3}$ (d: 77.0) or DMSO- $d_{6}$ (d: 39.5) solvent for ${ }^{13} \mathrm{C}-\mathrm{NMR}$, respectively. Multiplicities are abbreviated as $\mathrm{s}=$ singlet; $\mathrm{m}=$ multiplet; $\mathrm{br}=$ broad. Mass spectral data were determined on a Waters Acquity UPLC system (Waters, Milford, MA, USA) connected to a Waters SQ Detector-2 operating in the ESI positive ion mode on a Waters Acquity UPLC ${ }^{\circledR}$ BEH C18 column $(1.7 \mu \mathrm{m}, 2.1 \times 50 \mathrm{~mm})$ using a gradient elution with acetonitrile $(0.01 \%$ trifluoroacetic acid) in water $(0.01 \%$ trifluoroacetic acid) at a flow rate of $0.5 \mathrm{~mL} / \mathrm{min}$. LC-MS data were recorded with a Waters MassLynx 4.1 chromatography data system. Melting points (m.p.) of the synthesised compounds were determined on an OptiMelt (SRS Stanford Research Systems, Sunnyvale, CA, USA). Elemental analyses were determined on an Elemental Combustion System ECS 4010 (Costech Instruments, Pioltello, Italy).

Cell culture BHK-21 (baby hamster kidney fibroblast), Cos-7 (African green monkey kidney fibroblast-like), HeLa (human cervix epithelial cells), HepG2 (human liver epithelial), H2-35 (mouse liver hepatocytes), B16 (mouse melanoma), MCF-7 (human mammary gland adenocarcinoma), and Huh-7 (human hepato cellular carcinoma) cell lines were used in this study. Cells were cultured according to manufacturer's (American Type Culture Collection (ATCC), Rockville, MD, USA and Japanese Collection of Research Bioresources Cell Bank (JCRB), Osaka, Japan) provided guidelines at $37{ }^{\circ} \mathrm{C}$ and $5 \% \mathrm{CO}_{2}$.

Plasmids/pEGFP-C1 (4731 bp) (Clontech, Takara, Tokyo, Japan) was used for most studies (microscopy, complex formation assays). pRL-CMV (4079 bp) (Promega, Fitchburg, WI, USA) was used for transfection efficiency quantification by luciferase reporter assay. Both plasmids were transformed in Escherichia coli DH5 $\alpha$ and amplified in E. coli grown in LB media at $37^{\circ} \mathrm{C}$ for $16-18 \mathrm{~h}$. Plasmids were purified by a QIAGEN the EndoFree Plasmid Purification kit (Hilden, Germany). The purified plasmid DNA were dissolved in distilled water and stored at $-20{ }^{\circ} \mathrm{C}$. The purity and concentration of plasmid DNA were confirmed by a NanoDrop1000 spectrophotometer (Thermo Fischer Scientific (Waltham, MA, USA), and plasmids DNA were identified by agarose gel electrophoresis.

\subsection{Synthesis of compounds 1, 2 and D19 (Scheme 1)}

Compounds 1, 2 and D19. The 3,5-bis(dodecyloxycarbonyl)-2,6-dimethyl-4-phenyl-1,4-dihydropyrid ine (1); 2,6-di(bromomethyl)-3,5-bis(dodecyloxycarbonyl)-4-phenyl-1,4-dihydropyridine (2) and 1,1'-[(3,5-didodecyloxycarbonyl-4-phenyl-1,4-dihydropyridine-2,6-diyl)dimethylen]-bispyridinium dibromide (D19) were synthesised according to the previously-reported methods [23]. Briefly, the elaborated synthesis of the cationic derivative D19 involves three sequential steps. The first step was a synthesis of the starting 1,4-DHP derivative 1 in a two-component Hantzsch-type cyclisation; the second involved the bromination of the methyl groups 2,6-dimethyl-1,4-DHP derivative 1 with 
$N$-bromosuccinimide (NBS); and the third step was the nucleophilic substitution of bromine of compound 2 with pyridine yielding the target compound D19. ${ }^{1} \mathrm{H}$ - and ${ }^{13} \mathrm{C}-\mathrm{NMR}$ spectra data of compounds 1, 2, and D19 were identical to those reported in the literature [26].

Didodecyl 2,6-bis-(2-(N,N-dimethylamino)ethyl)-4-phenyl-1,4-dihydropyridine-3,5-dicarboxylate (3). A mixture of didodecyl 3,5-bis(dodecyloxycarbonyl)-2,6-dimethyl-4-phenyl-1,4-dihydropyridine (1, $1.22 \mathrm{~g}$, $2.00 \mathrm{mmol})$, paraformaldehyde $(0.40 \mathrm{~g}, 0.01 \mathrm{eq}, 0.02 \mathrm{~mol})$, dimethylamine hydrochloride $(0.98 \mathrm{~g}$, $12.0 \mathrm{mmol})$, a conc. $\mathrm{HCl}(0.150 \mathrm{~mL})$ and ethanol $(10 \mathrm{~mL})$ was refluxed for $24 \mathrm{~h}$. The solvent was removed by evaporation in vacuo, after which water $(5 \mathrm{~mL})$ was added. The $\mathrm{pH}$ of the resulting mixture was adjusted to approx. 8 with an aqueous solution of sodium carbonate and extracted with chloroform $(6 \times 30 \mathrm{~mL})$. The organic layer was washed with brine and dried over $\mathrm{MgSO}_{4}$. After removal of the solvent, the oily residue was obtained and purified by flash chromatography (eluent: chloroform:acetone:methanol: $\left.\mathrm{Et}_{3} \mathrm{~N}=9: 4: 2: 0.02\right)$ yielding $0.75 \mathrm{~g}(68 \%)$ of light yellow foam. TLC: $\mathrm{R}_{\mathrm{f}}: 0.2\left(\mathrm{CHCl}_{3} / \mathrm{MeOH} / \mathrm{Et}_{3} \mathrm{~N}=1: 1: 0.01\right) .{ }^{1} \mathrm{H}-\mathrm{NMR}\left(\mathrm{CDCl}_{3}\right): \delta 0.86-0.90(\mathrm{~m}, 6 \mathrm{H}), 1.23-1.34(\mathrm{~m}, 36 \mathrm{H})$; $1.55-1.60(\mathrm{~m}, 4 \mathrm{H}), 2.33(\mathrm{~s}, 12 \mathrm{H}), 2.52-2.66(\mathrm{~m}, 4 \mathrm{H}), 2.90-3.09(\mathrm{~m}, 4 \mathrm{H}), 3.98-4.02(\mathrm{~m}, 4 \mathrm{H}), 4.98(\mathrm{~s}, 1 \mathrm{H})$, 7.08-7.12 (m, 1H), 7.16-7.20 (m, 2H), 7.26-7.27 (m, 2H), $10.13(\mathrm{~s}, 1 \mathrm{H})$ ppm. ${ }^{13} \mathrm{C}-\mathrm{NMR}\left(\mathrm{CDCl}_{3}\right): \delta 14.1$, 18.4, 22.7, 26.1, 27.8, 28.7, 29.3, 29.4, 29.5, 29.6, 29.7, 31.9, 37.0, 39.4, 44.7, 63.8, 69.2, 102.8, 125.9, 127.7, 127.8, 148.2, 148.3, 167.7 ppm. MS (+ESI) $m / z$ (relative intensity); $725\left([\mathrm{M}+\mathrm{H}]^{+}, 60\right)$. Anal. calcd. for $\mathrm{C}_{45} \mathrm{H}_{77} \mathrm{~N}_{3} \mathrm{O}_{4}$ : C, 74.64; H, 10.72; N, 5.80; Found: C, 74.49; H, 10.55; N, 5.91.

$N, N^{\prime}-\{[3,5-B i s($ dodecyloxycarbonyl)-4-phenyl-1,4-dihydropyridine-2,6-diyl]diethylene $\} b i s ~ N, N$-dimethyoctyl ammonium dibromide (C12-Man-Q). A mixture of compound 3 (290 mg, $0.4 \mathrm{mmol}, 1 \mathrm{eq})$ and 1-bromooctane (232 mg, $1.2 \mathrm{mmol}, 3 \mathrm{eq})$ in nitromethane $(3 \mathrm{~mL})$ and DMF (0.5 mL) was refluxed under argon for $48 \mathrm{~h}$. The solvents were removed in vacuo and the residue was triturated with a small amount of dry acetone. After cooling the precipitate was filtered off and crystallised from dry acetone yielding compound C12-Man-Q as a light yellow powder (222 mg, 50\%), mp 180-183 ${ }^{\circ} \mathrm{C} .{ }^{1} \mathrm{H}-\mathrm{NMR}$ $\left(\mathrm{CDCl}_{3}\right): \delta 0.79-0.84(\mathrm{~m}, 12 \mathrm{H}), 1.21-1.30(\mathrm{~m}, 56 \mathrm{H}), 1.53(\mathrm{br} \mathrm{s}, 4 \mathrm{H}), 1.60-1.87(\mathrm{~m}, 8 \mathrm{H}), 3.22-3.38(\mathrm{~m}$, 2H)overlap, $3.36(\mathrm{~s}, 12 \mathrm{H})$ overlap, 3.48-3.56 (m, 2H), 3.65-3.73 (m, 2H), 3.85-3.97 (m, 4H), 4.24-4.35 (m, $2 \mathrm{H}), 4.74(\mathrm{~s}, 1 \mathrm{H}), 7.04-7.08(\mathrm{~m}, 1 \mathrm{H}), 7.12-7.15(\mathrm{~m}, 2 \mathrm{H}), 7.20-7.26(\mathrm{~m}, 2 \mathrm{H})$ overlap with $\mathrm{CDCl}_{3}, 10.02(\mathrm{~s}$, 1H) ppm. ${ }^{13} \mathrm{C}-\mathrm{NMR}\left(\mathrm{CDCl}_{3}\right): \delta 14.0,14.1,22.5,22.6,29.3,29.6,29.7,31.9,39.2,51.3,51.8,61.6,64.1,64.7$, 105.4, 126.4, 127.9, 128.0, 143.6, 147.2, 166.9 ppm. MS (+ESI) $\mathrm{m} / z$ (relative intensity); $950\left([\mathrm{M}-2 \mathrm{Br}+\mathrm{H}]^{+}\right.$ 10). Anal. calcd. for $\mathrm{C}_{61} \mathrm{H}_{111} \mathrm{Br}_{2} \mathrm{~N}_{3} \mathrm{O}_{4}$ : $\mathrm{C}, 65.98 ; \mathrm{H}, 10.08 ; \mathrm{N}$, 3.78; Found: $\mathrm{C}, 65.71 ; \mathrm{H}, 10.15 ; \mathrm{N}, 3.72$.

\subsection{Calculation of Nitrogen to Phosphorus (N/P) Ratio}

The N/P ratio is a measure of the ionic balance of the amphiphile/DNA complexes. The positive charge $(\mathrm{N})$ of amphiphile originates from the nitrogens of 1,4-DHP amphiphiles C12-Man-Q or D19. The negative charge $(\mathrm{P})$ in the plasmid DNA backbone arises from the phosphate group of the deoxyribose nucleotides. The average molecular weight of the nucleotides is assumed to be $330 \mathrm{~g} / \mathrm{mol}$.

Example of N/P ratio calculation: Complexation of $1 \mu \mathrm{g}$ of plasmid DNA with C12-Man-Q at $\mathrm{N} / \mathrm{P}$ ratio 1 , how much $0.5 \mathrm{mM}$ of $\mathbf{C} 12-\mathrm{Man}-\mathrm{Q}\left(V_{\mathrm{C} 12 \mathrm{Man} \mathbf{Q}_{\text {needed }}}\right)$ is needed?

$$
\begin{gathered}
\frac{N}{P}=\frac{1 \times 10^{-6}}{330}=3 \times 10^{-9} M=3 \mathrm{nmol} \\
N=P \times 1=3 \times 1=3 \\
V_{\mathrm{C} 12 \text { Man }_{\text {needed }}}=1 \times 3=3 \mu \mathrm{L}
\end{gathered}
$$

\subsection{Preparation of Amphiphile/pDNA Complexes (Lipoplexes)}

The amphiphile/pDNA complexes were prepared using various amounts of cationic lipid and constant amount of pDNA, ensuring different N/P ratios. Firstly, cationic lipid and pDNA were diluted separately in various transfection media: (a) medium without any supplements; and (b) 
medium without any supplements, with additional $0.15 \mathrm{M} \mathrm{NaCl}$ solution; we also compared the complexes' efficiency made in those media, just with reduced volume. Secondly, after a 5-min long incubation time, diluted pDNA was added by droplets to diluted cationic reagent solution and the whole mixture was then incubated at room temperature for $15 \mathrm{~min}$.

Agarose gel retardation assay. The cationic amphiphile/pDNA complexes were prepared by adding $1 \mu \mathrm{g}$ of DNA to different concentrations of 1,4-DHP derivatives to obtain different N/P charge ratios. After gentle swirling, the mixtures were allowed to stand at room temperature for $10 \mathrm{~min}$ prior to analysis. The lipoplexes were prepared in media containing additional $0.15 \mathrm{M} \mathrm{NaCl}$ (for compounds D19 and C12-Man-Q) or in media without any additional supplements (for C12-Man-Q). After incubation time, gel running buffer with bromophenol blue was added to the complexes and they were loaded on $0.9 \%$ agarose gel in TAE buffer, $\mathrm{pH} 8$. Voltage of $65 \mathrm{~V}$ was applied for $2.5 \mathrm{~h}$. Following EtBr staining DNA bands were visualised in an UV transilluminator and photographed (BioSpectrum Imaging system, Upland, CA, USA).

\subsection{In Vitro Transfection Experiment}

Cells were seeded onto 24-well plates prior the experiment day with antibiotic-free media so that, at the time of transfection, cells reached $70-80 \%$ confluency. The final lipoplexes volume was $200 \mu \mathrm{L}$ or $100 \mu \mathrm{L}$ (in case the dilution volume was reduced) and the DNA were used at a concentration of $1 \mu \mathrm{g} /$ well. Before adding lipoplex solutions, old cell culture medium was removed and cells were washed once with serum-free medium, and the above 200 or $100 \mu \mathrm{L}$ lipoplexes were added to each well. Plates were incubated for 1.5 to $3 \mathrm{~h}$ at $37{ }^{\circ} \mathrm{C}$ in a humidified atmosphere containing $5 \% \mathrm{CO}_{2}$. At the end of the incubation period, into each well fresh medium containing $10 \%$ FBS was added. Plates were further incubated for a period of $24 \mathrm{~h}$ before evaluating the expression of the reporter gene.

\subsubsection{Cytotoxicity Assay}

Cytotoxicity of lipoplexes towards used cells was determined using an MTT (3-(4,5-dimethylthiazo 1-2-yl)-2,5-diphenyltetrazolium bromide) reduction assay. Twenty-four hours post transfection, culture medium was removed and cells were washed once with PBS. Then $270 \mu \mathrm{L}$ of medium without phenol red and $30 \mu \mathrm{L}$ of MTT solution (MTT powder was diluted into medium without phenol red in proportion $-15 \mathrm{mg}$ powder into $3 \mathrm{~mL}$ of medium) was added to each well. The plate was then incubated for $2 \mathrm{~h}$ at $37{ }^{\circ} \mathrm{C}$ in a humidified atmosphere containing $5 \% \mathrm{CO}_{2}$. After incubation time $300 \mu \mathrm{L}$ of MTT solvent (10\% Triton X-100, $0.1 \mathrm{~N} \mathrm{HCl}$ anhydrous isopropanol, $125 \mathrm{~mL}$ ) was added to each well, and cells were suspended in order to promote dissolution of formed formazan crystals. The absorbance was measured using an FL $\times 800$ fluorescence microplate reader (Biotek, Vernusky, VT, USA) at wavelengths of 570 and $690 \mathrm{~nm}$.

\subsubsection{Assessment of Transfection's Efficiency}

For fluorescent microscopy assays, cells were transfected by complexes containing pEGFP-C1. Twenty-four hours after the transfection, the microscope images were obtained at magnifications of $100 \times$ and 400× recorded with Leica DC 150 camera system (Meyer Instruments Inc., Houston, TX, USA) and processed with the open access image processing and analysing program ImageJ.

For luciferase assays, cells were transfected with complexes containing pRL-CMV. For a typical assay in a 24-well plate, $24 \mathrm{~h}$ post transfection old medium was removed from the wells and the cells were washed once with PBS. In accordance with the Renilla luciferase assay system (Promega, USA) manufacturer, $100 \mu \mathrm{L}$ of luciferase lysis buffer was then added to each well, and the cells were lysed for $15 \mathrm{~min}$ at room temperature. The cell lysate was transferred to Eppendorf tubes and centrifuged $\left(11,000 \mathrm{rpm}\right.$ for $10 \mathrm{~min}$ at $\left.8{ }^{\circ} \mathrm{C}\right)$. For the assay, $20 \mu \mathrm{L}$ of this supernatant, and $50 \mu \mathrm{L}$ of luciferase assay substrate (Promega, USA), were used. The luciferase activity was measured in a luminometer Thermo Luminoskan Ascent Reader (Thermo Fischer Scientific, USA) in standard kinetic-luminiscence mode. The integration time of the measurement was $10 \mathrm{~s}$, and a delay of $2 \mathrm{~s}$ 
was given before each measurement. Comparisons of transfection efficiency of various transfection complexes was made based on data for luciferase expressed as relative light units (RLU), normalised for 10,000 cells. All the experiments were done in triplicate, and the results presented are the average of those independent experiments.

\subsubsection{Sample Preparation for Confocal Laser Scanning Microscopy}

BHK-21 cells were plated onto glass chamber slides for cytochemistry. After $24 \mathrm{~h}$ growing cells were transfected with pEGFP-C1 using novel cationic compounds C12-Man-Q and D19. At 3-24 h post transfection the cells were washed with PBS and fixed with 3.7\% formaldehyde (Sigma-Aldrich, USA) for $15 \mathrm{~min}$ at $+37^{\circ} \mathrm{C}$. Cell nuclei were counterstained with DAPI (c $=4 \mu \mathrm{g} / \mathrm{mL}$ ) (Sigma-Aldrich, USA) for 7 min. ProLong ${ }^{\circledR}$ Antifade Kit (P7481) (Molecular Probes/Invitrogen, Eugene, OR, USA) was used for cell mounting. Studies were performed by a Leica DM 6000 B microscope (Leica Microsystems CMS GmbH, Wetzlar, Germany) with a Leica TCS SP2 SE AOBS ${ }^{\circledR}$ laser scanning confocal system (Leica Microsystems CMS GmbH, Wetzlar, Germany).

\subsubsection{Sample Preparation for Transmission Electron Microscopy Studies}

Samples were prepared as described above (see: Preparation of Liposome/pDNA Complexes (Lipoplexes)), however, DNA and cationic lipids were diluted into the water. The concentration of cationic lipid for electron microscopy was $0.5 \mu \mathrm{g} / \mu \mathrm{L}$ and, therefore, we calculated the exact amount of pDNA and the volume of cationic lipid. One drop of the sample was adsorbed to a formvar carbon-coated copper grid and negatively stained with $1 \%$ aqueous solution of uranyl acetate. The grids were examined with a JEM-1230 TEM (Jeol, Tokyo, Japan) at 100 kV.

\subsection{Statistical Analysis}

Data statistical analysis was performed using the open source programming language and software environment for statistical computing and graphics program R [53]. Two sample $t$-test, regression analysis, as well as analysis of covariance (ANCOVA), were performed. Statistical significance was set at $p<0.05$.

\section{Conclusions}

We tested and compared two novel cationic compounds, D19 and C12-Man-Q, on a 1,4-DHP core as nonviral liposome-based transfection agents. A new amphiphilic 1,4-DHP derivative, C12-Man-Q, was synthesised with more remoted cationic moieties at positions 2 and 6 than for the parent compound D19. Additionally, instead of aromatic pyridinium moieties, aliphatic ammonium moieties were introduced into the C12-Man-Q molecule as cationic headgroups. The results were compared with data obtained for cationic 1,4-DHP derivative D19, which is known to be the most efficient one among the previously tested 1,4-DHP amphiphiles. In this study we evaluated the effects of C12-Man-Q concentration, complexation media, and complex contact time on the gene delivery effectiveness and cell viability.

Obtained data confirmed that both cationic 1,4-DHP derivatives have the ability to bind pDNA, though their performance of transfecting cells differ significantly. To increase transfection efficiency and reduce toxic cell effects of compound C12-Man-Q we found the optimal transfection complex preparation medium (without any supplements) and reduced the transfection complex/cell contact time to $1.5 \mathrm{~h}$. We also explored an optimal $\mathrm{N} / \mathrm{P}$ ratio of 0.9 for this compound, when transfection efficiency was quite good, and cell viability after transfection was also within the acceptable range.

We evaluated the transfection activity of lipoplexes formed by 1,4-DHP derivatives D19 and C12-Man-Q with pDNA in various cell lines: BHK-21, Cos7, H2-35, B16, MCF-7, HeLa, Huh-7, and HepG2. The most significant property of compound C12-Man-Q is its moderate, but still steady, ability to transfect many cell lines, with higher effectiveness in the case of H2-35 and B16 cell lines. The experimental results showed that compound C12-Man-Q effectively delivered plasmid DNA 
into many eukaryotic cell lines, while compound D19 was defined as cell type specific and possesses higher transfection efficiency in the case of BHK-21 and Cos-7 cell lines.

Author Contributions: B.V. and T.K. conceived and designed the experiments; G.A. I.T., A.V., B.V., M.R., M.P., and A.S. performed the experiments; K.P., M.P., A.V., G.A., and A.P. analysed the data; I.T., K.P., and A.S. contributed reagents/materials/analysis tools; and A.P., G.A., and T.K. wrote the paper.

Funding: This research was funded by the National Research programme "Biomedicine for Public Health" (BIOMEDICINE) (2014-2017): Project: No 3 "Development of novel anticancer drugs and immunotherapeutic approaches".

Acknowledgments: We are indebted to Dr.habil. V.Ose for transmission electron microscopy analysis.

Conflicts of Interest: The authors declare no conflict of interest.

\section{References and Note}

1. Wirth, T.; Parker, N.; Ylä-Herttuala, S. History of gene therapy. Gene 2013, 525, 162-169. [CrossRef] [PubMed]

2. Foldvari, M.; Chen, D.W.; Nafissi, N.; Calderon, D.; Narsineni, L.; Rafiee, A. Non-viral gene therapy: Gains and challenges of non-invasive administration methods. J. Control. Release 2016, 240, 165-190. [CrossRef] [PubMed]

3. Keeler, A.M.; ElMallah, M.K.; Flotte, T.R. Gene Therapy 2017: Progress and Future Directions. Clin. Transl. Sci. 2017, 10, 242-248. [CrossRef] [PubMed]

4. Cox, D.B.T.; Platt, R.J.; Zhang, F. Therapeutic genome editing: Prospects and challenges. Nat. Med. 2015, 21, 121. [CrossRef] [PubMed]

5. Khan, S.; Ullah, M.W.; Siddique, R.; Nabi, G.; Manan, S.; Yousaf, M.; Hou, H. Role of Recombinant DNA Technology to Improve Life. Int. J. Genom. 2016, 2016, 14. [CrossRef] [PubMed]

6. Scholz, C.; Wagner, E. Therapeutic plasmid DNA versus siRNA delivery: Common and different tasks for synthetic carriers. J. Control. Release 2012, 161, 554-565. [CrossRef] [PubMed]

7. Wang, K.; Kievit, F.M.; Zhang, M. Nanoparticles for cancer gene therapy: Recent advances, challenges, and strategies. Pharmacol. Res. 2016, 114, 56-66. [CrossRef] [PubMed]

8. El-Aneed, A. Current strategies in cancer gene therapy. Eur. J. Pharmacol. 2004, 498, 1-8. [CrossRef] [PubMed]

9. Morille, M.; Passirani, C.; Vonarbourg, A.; Clavreul, A.; Benoit, J.-P. Progress in developing cationic vectors for non-viral systemic gene therapy against cancer. Biomaterials 2008, 29, 3477-3496. [CrossRef] [PubMed]

10. Li, S.; Huang, L. Nonviral gene therapy: Promises and challenges. Gene Ther. 2000, 7, 31-34. [CrossRef] [PubMed]

11. Lv, H.; Zhang, S.; Wang, B.; Cui, S.; Yan, J. Toxicity of cationic lipids and cationic polymers in gene delivery. J. Control. Release 2006, 114, 100-109. [CrossRef] [PubMed]

12. Knudsen, K.B.; Northeved, H.; Kumar Ek, P.; Permin, A.; Gjetting, T.; Andresen, T.L.; Larsen, S.; Wegener, K.M.; Lykkesfeldt, J.; Jantzen, K.; et al. In vivo toxicity of cationic micelles and liposomes. Nanomedicine 2015, 11, 467-477. [CrossRef] [PubMed]

13. Anson, D.S. The use of retroviral vectors for gene therapy-what are the risks? A review of retroviral pathogenesis and its relevance to retroviral vector-mediated gene delivery. Genet. Vaccines Ther. 2004, 2, 9-10. [CrossRef] [PubMed]

14. Wu, T.-L.; Ertl, H.C.J. Immune barriers to successful gene therapy. Trends Mol. Med. 2009, 15, 32-39. [CrossRef] [PubMed]

15. Keles, E.; Song, Y.; Du, D.; Dong, W.-J.; Lin, Y. Recent progress in nanomaterials for gene delivery applications. Biomater. Sci. 2016, 4, 1291-1309. [CrossRef] [PubMed]

16. Zhou, Z.; Liu, X.; Zhu, D.; Wang, Y.; Zhang, Z.; Zhou, X.; Qiu, N.; Chen, X.; Shen, Y. Nonviral cancer gene therapy: Delivery cascade and vector nanoproperty integration. Adv. Drug Deliv. Rev. 2017, 115, 115-154. [CrossRef] [PubMed]

17. Prakash, K.P.; Arabinda, C. Cationic liposomes as non-viral carriers of gene medicines: Resolved issues, open questions, and future promises. Med. Res. Rev. 2007, 27, 696-722. [CrossRef]

18. Koynova, R.; Tenchov, B. Enhancing nucleic acid delivery, insights from the cationic phospholipid carriers. Curr. Pharm. Biotechnol. 2014, 15, 806-813. [CrossRef] [PubMed] 
19. Parvizi, P.; Jubeli, E.; Raju, L.; Khalique, N.A.; Almeer, A.; Allam, H.; Manaa, M.A.; Larsen, H.; Nicholson, D.; Pungente, M.D.; et al. Aspects of nonviral gene therapy: Correlation of molecular parameters with lipoplex structure and transfection efficacy in pyridinium-based cationic lipids. Int. J. Pharm. 2014, 461, 145-156. [CrossRef] [PubMed]

20. Ibraheem, D.; Elaissari, A.; Fessi, H. Gene therapy and DNA delivery systems. Int. J. Pharm. 2014, 459, 70-83. [CrossRef] [PubMed]

21. Hiwale, A.A.; Voshavar, C.; Dharmalingam, P.; Dhayani, A.; Mukthavaram, R.; Nadella, R.; Sunnapu, O.; Gandhi, S.; Naidu, V.G.M.; Chaudhuri, A.; et al. Scaling the effect of hydrophobic chain length on gene transfer properties of di-alkyl, di-hydroxy ethylammonium chloride based cationic amphiphiles. RSC Adv. 2017, 7, 25398-25405. [CrossRef]

22. Tirzite, D.; Koronova, J.; Plotniece, A. Influence of some quaternised 1,4-dihydropyridine derivatives on liposomes and erythrocyte membranes. Biochem. Mol. Biol. Int. 1998, 45, 849-856. [PubMed]

23. Hyvonen, Z.; Plotniece, A.; Reine, I.; Chekavichus, B.; Duburs, G.; Urtti, A. Novel cationic amphiphilic 1,4-dihydropyridine derivatives for DNA delivery. Biochim. Biophys. Acta Biomembr. 2000, 1509, 451-466. [CrossRef]

24. Pajuste, K.; Hyvonen, Z.; Petrichenko, O.; Kaldre, D.; Rucins, M.; Cekavicus, B.; Ose, V.; Skrivele, B.; Gosteva, M.; Morin-Picardat, E.; et al. Gene delivery agents possessing antiradical activity: Self-assembling cationic amphiphilic 1,4-dihydropyridine derivatives. New J. Chem. 2013, 37, 3062-3075. [CrossRef]

25. Petrichenko, O.; Rucins, M.; Vezane, A.; Timofejeva, I.; Sobolev, A.; Cekavicus, B.; Pajuste, K.; Plotniece, M.; Gosteva, M.; Kozlovska, T.; et al. Studies of the physicochemical and structural properties of self-assembling cationic pyridine derivatives as gene delivery agents. Chem. Phys. Lipids 2015, 191, 25-37. [CrossRef] [PubMed]

26. Pajuste, K.; Plotniece, A.; Kore, K.; Intenberga, L.; Cekavicus, B.; Kaldre, D.; Duburs, G.; Sobolev, A. Use of pyridinium ionic liquids as catalysts for the synthesis of 3,5-bis(dodecyloxycarbonyl)-1,4-dihydropyridine derivative. Cent. Eur. J. Chem. 2011, 9, 143-148. [CrossRef]

27. Aritomi, J.; Ueda, S.; Nishimura, H. Mannich Reaction of Dihydropyridine Derivatives. I. Reactions with Secondary Amines. Chem. Pharm. Bull. 1980, 28, 3163-3171. [CrossRef]

28. Both compounds were analysed by HPLC on a Zorbax CN $(5 \mu \mathrm{m}, 4.6 \times 250 \mathrm{~mm}$, Agilent, Santa Clara, CA, USA) column using a mobile phase of acetonitrile/0.05 M phosphate buffer, $\mathrm{pH} 2$ (80:20 by volume) at a flow rate of $1.5 \mathrm{~mL} / \mathrm{min}$ with detection at UV $210 \mathrm{~nm}$. Under the conditions analysed, the retention times of D-19 and C12-Man-Q were 5.5 and 3.3 min, respectively.

29. Hardee, C.L.; Arévalo-Soliz, L.M.; Hornstein, B.D.; Zechiedrich, L. Advances in non-viral DNA vectors for gene therapy. Genes 2017, 8. [CrossRef] [PubMed]

30. Wang, Z.; Jin, L.; Yuan, Z.; Węgrzyn, G.; Węgrzyn, A. Classification of plasmid vectors using replication origin, selection marker and promoter as criteria. Plasmid 2009, 61, 47-51. [CrossRef] [PubMed]

31. Román, R.; Miret, J.; Scalia, F.; Casablancas, A.; Lecina, M.; Cairó, J.J. Enhancing heterologous protein expression and secretion in HEK293 cells by means of combination of CMV promoter and IFN $\alpha 2$ signal peptide. J. Biotechnol. 2016, 239, 57-60. [CrossRef] [PubMed]

32. Prasher, D.C.; Eckenrode, V.K.; Ward, W.W.; Prendergast, F.G.; Cormier, M.J. Primary structure of the Aequorea victoria green-fluorescent protein. Gene 1992, 111, 229-233. [CrossRef]

33. Chalfie, M.; Tu, Y.; Euskirchen, G.; Ward, W.W.; Prasher, D.C. Green fluorescent protein as a marker for gene expression. Science 1994, 263, 802-805. [CrossRef] [PubMed]

34. Inouye, S.; Tsuji, F.I. Evidence for redox forms of the Aequorea green fluorescent protein. FEBS Lett. 1994, 351, 211-214. [CrossRef]

35. Van Gaal, E.V.B.; van Eijk, R.; Oosting, R.S.; Kok, R.J.; Hennink, W.E.; Crommelin, D.J.A.; Mastrobattista, E. How to screen non-viral gene delivery systems in vitro? J. Control. Release 2011, 154, 218-232. [CrossRef] [PubMed]

36. Van Gaal, E.V.B.; Oosting, R.S.; van Eijk, R.; Bakowska, M.; Feyen, D.; Kok, R.J.; Hennink, W.E.; Crommelin, D.J.A.; Mastrobattista, E. DNA Nuclear Targeting Sequences for Non-Viral Gene Delivery. Pharm. Res. 2011, 28, 1707-1722. [CrossRef] [PubMed]

37. Hofland, H.E.; Shephard, L.; Sullivan, S.M. Formation of stable cationic lipid/DNA complexes for gene transfer. Proc. Natl. Acad. Sci. USA 1996, 93, 7305-7309. [CrossRef] [PubMed] 
38. Doyle, S.R.; Chan, C.K. Differential intracellular distribution of DNA complexed with polyethylenimine (PEI) and PEI-polyarginine PTD influences exogenous gene expression within live COS-7 cells. Genet. Vaccines Ther. 2007, 5, 11. [CrossRef] [PubMed]

39. De los Milagros Bassani Molinas, M.; Beer, C.; Hesse, F.; Wirth, M.; Wagner, R. Optimizing the transient transfection process of HEK-293 suspension cells for protein production by nucleotide ratio monitoring. Cytotechnology 2014, 66, 493-514. [CrossRef] [PubMed]

40. Even-Chen, S.; Cohen, R.; Barenholz, Y. Factors affecting DNA binding and stability of association to cationic liposomes. Chem. Phys. Lipids 2012, 165, 414-423. [CrossRef] [PubMed]

41. Schneider, C.A.; Rasband, W.S.; Eliceiri, K.W. NIH Image to ImageJ: 25 years of image analysis. Nat. Methods 2012, 9, 671. [CrossRef] [PubMed]

42. Ross, P.C.; Hui, S.W. Lipoplex size is a major determinant of in vitro lipofection efficiency. Gene Ther. 1999, 6, 651. [CrossRef] [PubMed]

43. Rak, M.; Ochałek, A.; Bielecka, E.; Latasiewicz, J.; Gawarecka, K.; Sroka, J.; Czyż, J.; Piwowarczyk, K.; Masnyk, M.; Chmielewski, M.; et al. Efficient and non-toxic gene delivery by anionic lipoplexes based on polyprenyl ammonium salts and their effects on cell physiology. J. Gene Med. 2016, 18, 331-342. [CrossRef] [PubMed]

44. Oskuee, R.K.; Mahmoudi, A.; Gholami, L.; Rahmatkhah, A.; Malaekeh-Nikouei, B. Cationic Liposomes Modified with Polyallylamine as a Gene Carrier: Preparation, Characterization and Transfection Efficiency Evaluation. Adv. Pharm. Bull. 2016, 6, 515-520. [CrossRef] [PubMed]

45. Tolosa, L.; Donato, M.T.; Gómez-Lechón, M.J. General Cytotoxicity Assessment by Means of the MTT Assay. In Protocols in In Vitro Hepatocyte Research; Vinken, M., Rogiers, V., Eds.; Springer: New York, NY, USA, 2015; pp. 333-348.

46. Smale, S.T. Luciferase Assay. Cold Spring Harbor Protoc. 2010, 2010, 2010. [CrossRef] [PubMed]

47. Meidan, V.M.; Cohen, J.S.; Amariglio, N.; Hirsch-Lerner, D.; Barenholz, Y. Interaction of oligonucleotides with cationic lipids: The relationship between electrostatics, hydration and state of aggregation1. Biochim. Biophys. Acta Biomembr. 2000, 1464, 251-261. [CrossRef]

48. Zuhorn, I.S.; Hoekstra, D. On the Mechanism of Cationic Amphiphile-mediated Transfection. To Fuse or not to Fuse: Is that the Question? J. Membr. Biol. 2002, 189, 167-179. [CrossRef] [PubMed]

49. Hoekstra, D.; Rejman, J.; Wasungu, L.; Shi, F.; Zuhorn, I. Gene delivery by cationic lipids: In and out of an endosome. Biochem. Soc. Trans. 2007, 35, 68-71. [CrossRef] [PubMed]

50. Jacobsen, L.B.; Calvin, S.A.; Lobenhofer, E.K. Transcriptional effects of transfection: The potential for misinterpretation of gene expression data generated from transiently transfected cells. BioTechniques 2009, 47,617-624. [CrossRef] [PubMed]

51. Ma, B.; Zhang, S.; Jiang, H.; Zhao, B.; Lv, H. Lipoplex morphologies and their influences on transfection efficiency in gene delivery. J. Control. Release 2007, 123, 184-194. [CrossRef] [PubMed]

52. Sakaguchi, N.; Kojima, C.; Harada, A.; Koiwai, K.; Kono, K. The correlation between fusion capability and transfection activity in hybrid complexes of lipoplexes and pH-sensitive liposomes. Biomaterials 2008, 29, 4029-4036. [CrossRef] [PubMed]

53. R Core Team. R: A Language and Environment for Statistical Computing; R Foundation for Statistical Computing: Vienna, Austria, 2013; Available online: http:/ / www.R-project.org/ (accessed on 30 April 2018).

Sample Availability: Samples of the compounds D19 and C12-Man-Q are available from the authors. 